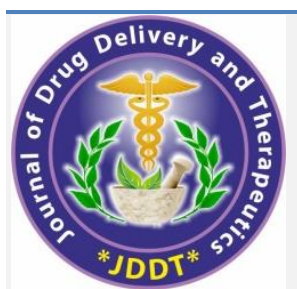

Open Access Full Text Article

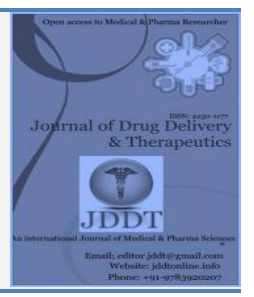

Research Article

\title{
The Effect of Various Concentrations of Ethanol Extract of the Leaves of Paederia foetida L. on the Growth of Escherichia Coli Bacteria
}

\author{
Hertina Silaban \\ Medical Faculty, Universitas Kristen Indonesia, Jakarta, Indonesia
}

\section{Article Info:}

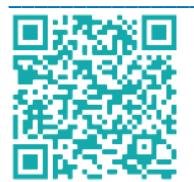

\section{Article History:}

Received 16 September 2021 Reviewed 21 October 2021 Accepted 29 October 2021

Published 15 November 2021

\section{Cite this article as:}

Silaban H, The Effect of Various Concentrations of Ethanol Extract of the Leaves of Paederia foetida L. on the Growth of Escherichia Coli Bacteria, Journal of Drug Delivery and Therapeutics. 2021; 11(6):6167

DOI: http://dx.doi.org/10.22270/jddt.v11i6.5029

\section{*Address for Correspondence:}

Hertina Silaban, Medical Faculty, Universitas Kristen Indonesia, Jakarta, Indonesia

\begin{abstract}
Bacterial infection of Escherichia coli (E. coli) as the cause of gastrointestinal disorders in humans has increased their prevalence. Treatment using natural ingredients can be a choice of therapy because of the minimal side effects. One of the rare plants believed by the community as an antibacterial is stinking vin'e known as the 'leaf fart'. The purpose of this research is for knowing the activity of the ethanol extract of Paederia foetida L can affect the growth of E.coli. The serial diffusion disc method is being used as the antibacterial activity test. The concentration of this extract are $10 \%, 20 \%, 40 \%, 80 \%, 100 \%$ with positive control (ciprofloxacin) and negative control (aqua dest). The inhibition zone diameter characterized the effect of Extract on bacterial growth were $6.16 \mathrm{~mm}$ of the concentration $10 \%, 6.667 \mathrm{~mm}$ of the concentration $20 \%, 7.10 \mathrm{~mm}$ of the concentration $40 \%, 7.78 \mathrm{~mm}$ of the concentration $80 \%$, and $10.03 \mathrm{~mm}$ of the concentration $100 \%$. As for the negative control has no effect. The study stated that the higher concentration of antibacterial agent used, the greater the inhibition zone formed. Based on the result of the analysis of the data by using the One-Way ANOVA Test showed a probability value $(\mathrm{p})=0.000$ or value $(\mathrm{p})<0.05$, that $\mathrm{H}_{0}$ is rejected and $\mathrm{H}_{1}$ is accepted. The conclusion is that the Extract of stinking vin'e has an antibacterial effect on the growth of E.coli.
\end{abstract}

Keywords: Antibacterial, E.coli, Extract of Sembukan leaf

\section{INTRODUCTION}

E.coli is a typical microorganism in the human intestine, which is often one of the causes of health problems in humans.1,2 Bacteria that a veterinarian first discovered from Germany named Theodor Escheric in 1885 turned out to have four different classification groups, namely EPEC (Entero Pathogenic E-Coli), EIEC (Entero Toxigenic E-Coli), EHEC (Entero Hemorrhagic E-Coli). ), EIEC (Entero Invasive E-Coli), and EAEC (Entero Aggregative E-Coli).4,5,6 Microbiologically, these bacteria are often found in water sources, vegetables, and fruits that humans consume without proper processing. The author understands the habits of Indonesian people who usually consume raw food such as vegetables as fresh vegetables. This phenomenon will be severe because certain strains of E.coli can cause diarrhoea in humans. ${ }^{6}$

Human pathogenic E. coli $\mathrm{O}_{157} ; \mathrm{H}_{7}$ infections that are verotoxigenic in nature have caused 16,000 cases of foodborne disease (Food Borne Diseases) and 900 deaths per year in the United States, with an estimated annual cost of $\$ 200,000$ to $\$ 600,000 .{ }^{1}$ The 2013 Basic Health Research (Rikesdas) results showed that the incidence of diarrhoea in children under five in Indonesia was $6.7 \%$. The five provinces with the highest incidence of diarrhoea were Aceh 10.2\%, Papua 9.6\%, DKI Jakarta 8.9\%, South Sulawesi $8.1 \%$ and Banten $8.0 \% .^{7}$ Diarrhoea is an endemic disease in
Indonesia and is also a potential disease of Extraordinary Events (KLB) which is often accompanied by death. The 2016 Indonesian Health Profile shows that there have been three outbreaks of diarrhoea spread across three provinces, three districts, with 198 sufferers and six deaths. The incidence of national diarrhoea from the diarrhoea morbidity survey in 2014 was $270 / 1,000$ population, it is estimated that the number of diarrhoea sufferers in health facilities in 2016 was $6,897,463$ people. ${ }^{8}$

The use of antibacterial drugs is often used in handling this phenomenon. However, more and more people are aware of the side effects of antibiotic drugs, so not a few people are using herbal treatment. ${ }^{9}$ At this time, the use of traditional medicine is still in demand. It is believed to be the provision of our ancestors to treat diseases because the raw materials are easy to obtain, affordable prices, and can be cultivated by themselves, especially for people who still live in remote areas in Indonesia.

One of the traditional plants that the people trusted in ancient times to remedy digestive disorders such as diarrhoea is the Sembukan leaf (Paederia foetida L.). This leaf is known to emit this unpleasant odour when rubbed on the palms of the hands, and if eaten, it will cause a distinctive fart odour. The rotten smell is due to the active compound metal mercaptan in the leaves. ${ }^{10,11}$ The public well knows the benefits of healing plants. Some areas, such as Central Java, 
still serve Sembukan leaves as home food. They cook this plant as pipes along with grated young coconut and rotten tempeh. The mixture will be wrapped in banana leaves and then steamed. This side dish is commonly known as 'gembrot semukan'. Sembukan leaves are also known to have health benefits, including laxative fart, healing ulcers, dysentery, overcoming constipation, anti-inflammatory, detoxifying, and relieving spasms. The healing benefits are also felt by foreign people familiar with Sembukan leaves (Paederia foetida L.). The leaves of Sembukan have good antidiarrheal activity. ${ }^{10}$ Sembukan leaves contain secondary metabolites, such as alkaloids, saponins, tannins, and flavonoids, which in pharmacology have benefits like antioxidants, antibiotics, anticancer, anti-insects, antitumor agents, and immunomodulating agents. 12,13,14

The scientific evidence is shown through the research above further clarifies that Sembukan leaf (Paederia foetida L.) has excellent potential in the health sector. However, in Indonesia, research on Sembukan leaves is still relatively small. Therefore the authors are interested in conducting research that aims to determine the antibacterial activity of Sembukan leaves (Paederia foetida L.) against the growth of bacteria that cause digestive disorders in humans, especially E.coli. Based on the background of the problem above, the problems answered in this study are a) Does the ethanol extract of Sembukan leaves have antibacterial activity against the growth of Escherichia coli bacteria?, and b) What is the effect of several concentrations of ethanol extract of Sembukan leaves on the growth of Escherichia coli bacteria? The research objectives are a) The activity of ethanol extract of Sembukan leaves in influencing the growth of Escherichia coli bacteria, and b) The effect of several concentrations of ethanol extract of Sembukan leaves on the growth of Escherichia coli bacteria.

\section{LITERATURE REVIEW}

Sembukan leaves, often known as fart leaves, are among Indonesian medicinal plants originating from East Asia. Scientifically, this leaf is called Paederia foetida L. Description foetida indicates that this plant is a type of plant that smells bad.10,15 Based on history, the term 'Paederia' is a derivative term derived from the Greek, namely Paederos, which means cat's eye. In contrast, the term 'sembukan' is usually used by native Malays. Unlike the case with the Sundanese people who call this leaf the term 'kahitutan', while in the Ternate area, it is known as 'gumi siki' and on the island of Sumatra, it is known as 'fart leaf'.15 The people of Indonesia do not only feel the existence of this plant as a medicine but in China, this plant is known as 'Ji shit eng', while in English, it is known as 'stinking vin'e'.10

Morphologically, Sembukan leaf is a type of plant that propagates quickly to a height of 5-10 m. Although the leaf smell is unpleasant, the growth of the Sembukan leaves is complemented by flowers arranged in a compound with a length of 4-30 mm. This plant has elongated round leaves measuring $6-10 \mathrm{~cm}$, while the width is $3-5 \mathrm{~cm}$ and also the base of the leaves is heart-shaped or rounded. The edges of this plant's leaves are flat, and the tip is pointed, the base is grooved, has fine hairs, pinnate bones, rounded petioles, and has a booklet. The Sembukan plant also has a 4-6 mm round fruit diameter, shiny and yellow. ${ }^{10,11,15}$ Sembukan plants can thrive in sandy, loam, and even clay soils. Besides that, they can also grow in acidic, neutral, or alkaline soil conditions. Stem cuttings can propagate this plant. When viewed in terms of maintenance, this plant is relatively easy to maintain. It is enough to maintain watering, humidity, and fertilization.
Many chemical compounds are found in the Sembukan plant (Paederia foetida L.), including asperuloside, deacetylasperuloside, paederoside, and iridoid glycosides, paderosidic acid, arbutin, gamma sitosterol, and essential oils. ${ }^{15,16,17}$ The ethanol extract of Sembukan leaves is potentially an anti-inflammatory with a $20 \mathrm{mg} / \mathrm{kg}$ BW [ 17]. In addition, Sembukan plants also contain indole and methyl mercaptan compounds. The content of this methyl mercaptan compound is what causes the rotten smell of healed plants. Meanwhile, chemically active compounds that are thought to have antibacterial properties are flavonoids, saponins and tannins. ${ }^{18}$

Sembukan leaves contain secondary metabolite compounds that have many benefits. This study uses the maceration method. The Sembukan leaves were immersed in $96 \%$ ethanol and methanol for five days, then the ethanol extract and methanol Extract on each leaf and stem were analyzed using chemical reagents to identify alkaloids and saponins tannins and flavonoids. The results of phytochemical screening showed that the ethanol and methanol extracts of Sembukan stems contained alkaloids, saponins, tannins and flavonoids. In contrast, the ethanol and methanol extracts of Sembukan leaves contain alkaloids, tannins, and flavonoids. ${ }^{12}$ In pharmacology, secondary metabolite compounds are used as medicinal ingredients such as antioxidants, antibiotics, anticancer, anti-insects, antitumor agents, and immunomodulating agents.12,13,14 Alkaloid secondary metabolite compounds contained in the leaves of the Sembukan contain nitrogen and are alkaline. Alkaloids have pharmacological effects, including a trigger for the nervous system, antibacterial and anti-fungal, treat heart disease, raise blood pressure and others. ${ }^{12}$

Flavonoids are one of the secondary metabolites contained in plants. Flavonoids for plants function to protect themselves from disease and the surrounding environment. The function of flavonoids for the human body is to prevent cardiovascular disease because flavonoids are phenolic compounds with antioxidant properties that prevent cell damage by reactive free radicals. ${ }^{19}$ Flavonoids in plants function as growth regulators, photosynthetic regulation, antimicrobial and antiviral. The action of flavonoids as an antibacterial is to form complex compounds with extracellular and dissolved proteins to damage bacterial cell membranes and are followed by the release of intracellular compounds.9,18 These compounds will interfere with energy metabolism similarly to inhibiting the respiratory system because sufficient energy is required for the active absorption of various metabolites and the biosynthesis of macromolecules. Saponins as antibacterial are lowering the surface tension, resulting in increased permeability of cell leakage and the release of intracellular compounds. These compounds diffuse through the outer membrane and vulnerable cell walls, then bind to the cytoplasmic membrane and reduce the stability of the membrane. It causes the cytoplasm to leak out of the cell resulting in cell death. Antimicrobial agents that disrupt the cytoplasmic membrane are bactericidal.6,18

Tannins are polyphenolic compounds that have large molecular weights consisting of hydroxy and carboxyl groups. Tannin compounds consist of two types, namely condensed tannins and hydrolyzed tannins. ${ }^{9}$ Tannins work by forming hydrophobic complexes with proteins, inactivating adhesins, enzymes, and cell wall transport proteins, thereby interfering with the growth of microorganisms. Tannins are suspected as antimicrobial compounds due to their spasmolytic effect. The spasmolytic effect can shrink the bacterial cell wall so that the permeability of the bacterial cell is disrupted. Tannins also 
have antibacterial power by precipitation of protein because it is suspected that tannins have the same effect as phenolic compounds. ${ }^{18}$ Based on research conducted by Ummah in 2010, tannin compounds in starfruit leaf extract (Averrhoa bilimbi L.) are antibacterial against Staphylococcus aureus and Escherichia coli.20

Extracts are dry, viscous or liquid preparations made by extracting vegetable or animal simplicia according to a suitable method, outside the influence of direct sunlight.18 The extraction process is the separation of materials from the mixture by using a suitable solvent. The extraction process was stopped when equilibrium was reached between the compound concentration in the solvent and the plant cells. ${ }^{21}$ The quality of the Extract obtained depends on the solvent used. Selective solvents can produce extracts containing only the desired compound. The factors that need to be considered in selecting solvents are selectivity, safety, economy, ease of operation, and environmental friendliness. The quality that is allowed is that which meets the pharmaceutical requirements or known as pharmaceutical grade specifications. Several types of solvents are available: a) Aliphatic hydrocarbons are hexane and cyclohexane; b) Aromatic hydrocarbons are toluene, benzene; c) Chlorinated hydrocarbons are dichloromethane, carbon tetrachloride (chloroform); d) Alcohols such as methanol, ethanol, propanol, and butanol; e) Ketones such as acetone, methylethylketone; f) Carboxylic acids such as acetic acid; g) Esters such as ethyl acetate; h) Ether such as diethyl ether; i) Water that is transparent, colourless, tasteless, free of pathogenic germs and compounds that are harmful to health, and does not contain iron and other organic compounds; and j) Oil (rarely used).

Based on the water content, also known as liquid, viscous, and dry extracts. The liquid Extract still contains most of the solvent. Some solvents have been evaporated in the thick Extract, while the dry Extract contains no solvent. The extraction method is divided into several types, namely maceration method, percolation method, Soxhlet method, Reflux method or Steam Distillation Method, and Modified Maceration method (Ultrasound-Assisted Solvent Extraction Method).

E.coli, also called 'Bacterium coli commune, was first identified from the faeces of a baby in 1885 by a paediatrician from Germany named Theodor Escherich.4,5 E.coli is a normal flora in the intestines of humans and animals. E.coli is also considered a non-pathogenic bacterium in the digestive tract and can be considered a pathogenic bacterium if not in the digestive tract. 3,4

E.coli is a gram-negative bacteria with a temporary structure with a length of $2.0 \mathrm{~m}$, a diameter of $0.25-1.0 \mathrm{~m}$ and a cell volume of 0.6-0.7 m. The cell wall consists of peptidoglycan and an outer membrane. The cell wall of E.coli functions as self-protection from internal osmotic pressure that reaches 5-20 atmospheres and is also helpful in bacterial selfdivision. These bacteria do not have a nucleus. E.coli has villi which are thin filaments for capturing specific substrates and long peritrichous flagella as a means of locomotion when swimming. 3,4

E. coli is a facultative anaerobic bacterium that can give positive results for indole, lysine decarboxylation, gas production from glucose, and its ability to ferment lactose. These bacteria can grow at a temperature of $15-48^{\circ} \mathrm{C}$. The maximum growth rate of bacteria is in the temperature range of $37-42^{\circ} \mathrm{C}$. In addition, E.coli can also grow at $\mathrm{pH}$ conditions of $5.5-8.0$ and optimal growth in neutral $\mathrm{pH}$ conditions. However, some strains of E.coli that cause diarrheal disease can survive in poor $\mathrm{pH}$ conditions $(\mathrm{pH} 2.0)$. E.coli in urine can be identified quickly by looking at its hemolytic ability on blood agar, and the characteristic feature of Escherichia coli bacteria is the appearance of a "sheen" (shiny) colour on Eosin Methylene Blue (EMB) agar. 3,12

\section{RESEARCH METHOD}

This research is a laboratory experiment using the serial disc diffusion method known as the Kirby Baurer method. This sensitivity test was carried out by measuring the diameter of the clear zone, which was a sign that there was inhibition of the growth of E.coli bacteria by antibacterial compounds contained in the Extract of the Sembukan leaf. This research was conducted in September 2018 - November 2018 at the Microbiology Laboratory of the Medical Faculty, Universitas Kristen Indonesia, for bacterial inhibition testing and the Bogor Agricultural Institute's Biopharmaceutical Laboratory for extraction. The research subject was Escherichia coli ATCC 25922, which was obtained from the collection of the Department of Microbiology, Faculty of Medicine, University of Indonesia. The research sample used was Sembukan leaf extract. In this study, there were seven treatment groups, namely: distilled water as a negative control, concentrations of $10 \%, 20 \%, 40 \%, 80 \%, 100 \%$, and the antibiotic ciprofloxacin as a positive control. Based on the Federer formula, the number of repetitions in the seven treatment groups was obtained. So, the number of repetitions that can be done in each treatment group is four times. Data derived from the research results on the effect of Sembukan leaf extract on the growth of E.coli bacteria were analyzed using SPSS 24.0. The test that can be used on the number of samples $<30$ in this study is the One Way Anova test. This analytical test aims to analyze two variables, namely the dependent variable and the independent variable, to determine whether there is an effect of giving Sembukan leaf extract on the inhibition of the growth of E.coli bacteria. The interpretation of the analysis test, namely: a) If the p-value < (0.05), then $\mathrm{H}_{0}$ is rejected, and $\mathrm{H}_{1}$ is accepted. It shows that the sample data support the effect of Sembukan leaf extract (Paederia foetida L.) on the inhibition of the growth of E.coli bacteria, and b) If the p-value $>(0.05)$, then $\mathrm{H}_{0}$ is accepted and $\mathrm{H}_{1}$ is rejected. It shows that the sample data does not support the effect of giving Sembukan leaf extract on the inhibition of the growth of E. coli bacteria.

\section{RESULT AND DISCUSSION}

Sembukan leaf extract was made from $3 \mathrm{~kg}$ of fresh Sembukan leaves, which were then dried and yielded 385 grams of dried simplicia. Then 100 grams of powdered simplicia was extracted by maceration method and using analyzed ethanol solvent (PA), which was carried out at the Microbiology Laboratory of the Faculty of Medicine, Christian University of Indonesia and Phytopharmacy Laboratory, Bogor Agricultural University. The final result obtained is a thick extract of Sembukan leaves as much as 2.0 grams.

Bacterial culture was carried out using two different agar plate types: Nutrient Agar (NA) and Eosin Methylene Blue (EMB). Bacterial culture was carried out at the Microbiology Laboratory, Faculty of Medicine, Christian University of Indonesia. The stages of bacterial culture on agar plates can be seen in Appendix 4. 
Table 1: Bacterial Culture Results on Agar Plate

\begin{tabular}{|c|c|}
\hline Agar Plate Type & Colony Results \\
\hline Nutrient Agar (NA) & $\begin{array}{l}\text { Spread according to the zig-zag pattern formed, and the bacterial colonies are round and convex, } \\
\text { yellowish-white in colour, smooth, soft inconsistency, and have flat edges. } \\
\text { Figure 1: Escherichia coli Bacteria Culture Results on Nutrient Agar Plates [Source: Personal } \\
\text { Documentation] }\end{array}$ \\
\hline $\begin{array}{l}\text { Eosin Methylene Blue } \\
\text { (EMB) }\end{array}$ & $\begin{array}{c}\text { Figure 2: Bacterial Culture Results of Escherichia coli on Eosin Methylene Blue (EMB) Plate [Source: } \\
\text { Personal Documentation] }\end{array}$ \\
\hline
\end{tabular}

The method used in this study is the diffusion method with paper discs. E.coli bacteria were inoculated on MuellerHinton Agar, and then each agar was planted with seven paper discs consisting of five discs that had been soaked in different concentrations of Sembukan leaf extract, namely $10 \%, 20 \%, 40 \%, 80 \%, 100 \%$, and the other two discs were negative controls using distilled water and positive controls using ciprofloxacin antibiotics. The treatment was repeated at each concentration four times. Mueller-Hinton Agar which had been planted with seven discs, were then incubated at $37^{\circ} \mathrm{C}$ for 24 hours. The bright zone formed around the paper disc indicates an inhibitory response to bacterial growth by the active compounds found in the Extract of Sembukan leaves. The bright zone that is formed can be seen in the image below:

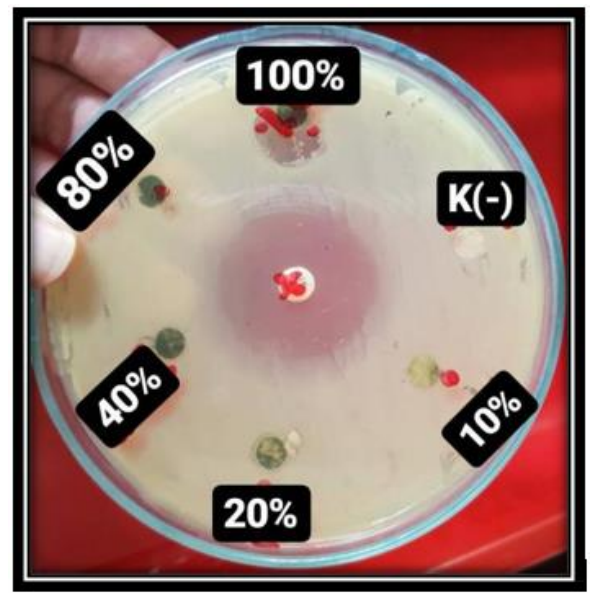

Figure 3: Results of Sensitivity Test Results of Sembukan Leaf Extract Against Escherichia coli Bacteria Inhibition [Source: Personal Documentation] 
Based on the results of research conducted using the inhibitory power of Sembukan leaves on the growth of E.coli conducted at the Microbiology Laboratory of the Medical
Faculty, Universitas Kristen Indonesia, in October, the following results were obtained:

Table 2: Results of Inhibitory Zone Measurements on E. coli Growth

\begin{tabular}{|c|c|c|c|c|c|c|}
\hline \multirow{2}{*}{ No } & \multirow{2}{*}{ Concentration } & \multicolumn{3}{|c|}{ Inhibition Zone Diameter (mm) } & \multirow{2}{*}{ Average (mm) } \\
\cline { 2 - 6 } & & I & II & III & IV & \\
\hline 1 & Control (+) Siprofloksasin & 32.025 & 31.025 & 34.20 & 30.45 & 31.925 \\
\hline 2 & Control (-)Aquades & 0 & 0 & 0 & 0 & 0 \\
\hline 3 & $10 \%$ & 6.125 & 6.30 & 6.125 & 6.10 & 6.1620 \\
\hline 4 & $20 \%$ & 6.30 & 7.025 & 7.15 & 6.175 & 6.6625 \\
\hline 5 & $40 \%$ & 7.475 & 7.25 & 7.225 & 6.475 & 7.1060 \\
\hline 6 & $80 \%$ & 8.025 & 8.425 & 7.45 & 7.15 & 7.7625 \\
\hline 7 & $100 \%$ & 8.30 & 9.425 & 9.125 & 13.3 & 10.0375 \\
\hline
\end{tabular}

The results of the above study indicate the presence of antimicrobial activity of Sembukan leaf extract on the growth of E.coli in the form of the formation of an inhibition zone on Mueller Hinton Agar which can be seen from the clear circle that does not contain E. coli bacterial colonies at concentrations of Sembukan leaf extract 10\%, 20\%, 40\%, $80 \%$, and $100 \%$. The positive control using the antibiotic ciprofloxacin in this study showed the largest bacterial inhibition zone, while the negative control using distilled water did not get a clear zone.

These results can also determine the inhibitory power of Sembukan leaf extract in inhibiting the growth of Escherichia coli bacteria. The criteria for the resistance strength can be explained based on the theory proposed by David and Stout in the table below:

Table 3: Criteria for Inhibitory Strength ${ }^{22}$

\begin{tabular}{|l|l|}
\hline $\begin{array}{l}\text { Inhibition Zone Diameter } \\
\text { (mm) }\end{array}$ & Inhibitory Properties \\
\hline$\geq 20$ & Very strong \\
$10-20$ & Strong \\
$5-10$ & Currently \\
$\leq 5$ & Weak \\
\hline
\end{tabular}

Based on Table 3, the inhibitory properties of the Sembukan leaf extract at the available concentrations are moderate, in contrast to the inhibitory properties of ciprofloxacin leaf extract as a positive control with powerful inhibitory properties. Based on the results described in Table 2, an increase in the bacterial inhibition zone was also obtained for each increase in the leaf extract concentration. The increasing graph in the inhibition zone formed by each different concentration can be seen in the image below:

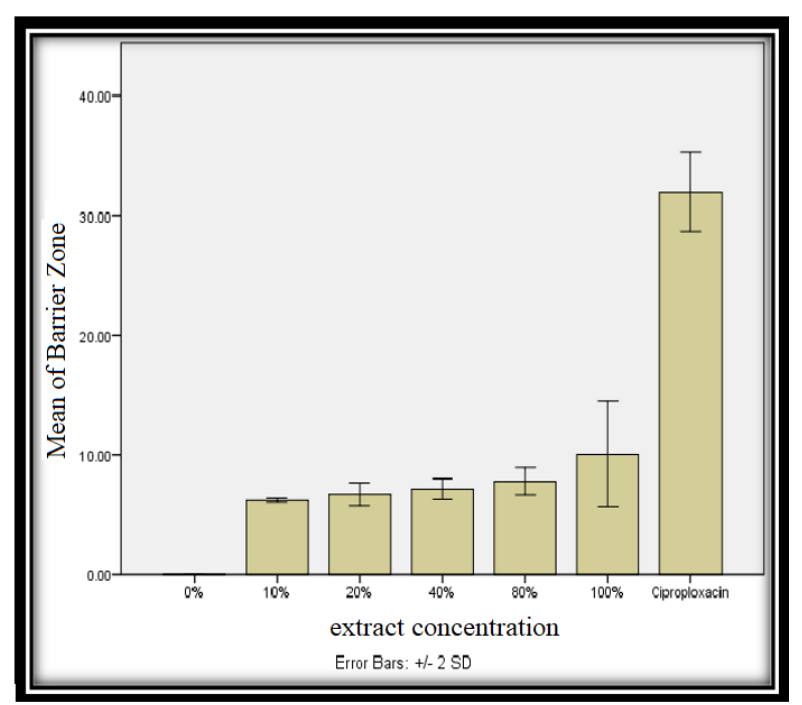

Figure 4: Graph of Increasing Bacterial Inhibition Zone Diameter

Based on Figure 4, it is obtained that the average diameter of the inhibition zone produced starting from a concentration of $10 \%$ continues to increase the graph to a concentration of $100 \%$, and the positive control occupies the highest value, while the negative control does not show any value on the graph.

One Way ANOVA test aims to determine the relationship between the independent variable and the dependent variable. $\mathrm{HO}$ is the null hypothesis which states that there is no relationship between the independent variable and the dependent variable, while $\mathrm{H} 1$ is the working hypothesis which states that there is a relationship between the independent variable and the dependent variable. If, in this study, the sig (p) $<0.05$ probability value, then $\mathrm{H} 0$ is rejected and $\mathrm{H} 1$ is accepted, which means that there is an effect of Sembukan leaf extract as an antibacterial on the growth of E.coli bacteria. The results of the One Way ANOVA test can be seen in the table below. 
Table 4: Results of One Way ANOVA Probability Test Score

\begin{tabular}{lllll}
\hline ANOVA & & & & \\
\hline Barrier Zone & & & & Sig. \\
\hline Variation & $\mathrm{df}$ & Rata-rata & 342. & .000 \\
\hline Between groups & 6 & 413.290 & 297 & \\
In Group & 21 & 1.207 & & \\
\hline Total & 27 & & &
\end{tabular}

Based on Table 4, the results show that the probability value (p) $=0.000$ or the value (p) $<0.05$ so that $\mathrm{H} 0$ is rejected and $\mathrm{H} 1$ is accepted. It means that the leaf extract of Sembukan has an antibacterial effect on the growth of E.coli bacteria.

Inhibition of microorganisms, one of which is influenced by the presence of active antimicrobial compounds. Ethanol and methanol extracts of Sembukan leaves contain alkaloids, tannins, and flavonoids, while the ethanol and methanol extracts of Sembukan stems contain alkaloids, saponins, tannins and flavonoids. ${ }^{11}$ These active compounds are antimicrobial due to their ability to form complexes with soluble extracellular proteins and microbial cell walls and work as type II topoisomerase inhibitors that inhibit bacterial DNA replication and transcription.

Based on the inhibition zone on four repetitions, the inhibition zone diameter was highest in the positive control using the antibiotic ciprofloxacin with diameters of 32.025 $\mathrm{mm}, 31.025 \mathrm{~mm}, 34.20 \mathrm{~mm}$, and $30.45 \mathrm{~mm}$, respectively. At a concentration of $10 \%$, the diameters were $6.125 \mathrm{~mm}, 6.30$ $\mathrm{mm}, 6.125$, and $6.10 \mathrm{~mm}$, respectively. At a concentration of $20 \%$, the diameters were $6.30 \mathrm{~mm}, 7.025 \mathrm{~mm}, 7.15$ and $6.175 \mathrm{~mm}$, respectively. At a concentration of $40 \%$, the diameters were $7.475 \mathrm{~mm}, 7.25 \mathrm{~mm}, 7.22 \mathrm{~mm}$, and 6.475 $\mathrm{mm}$, respectively. At a concentration of $80 \%$, the diameters were $8.025 \mathrm{~mm}, 8.425 \mathrm{~mm}, 7.45 \mathrm{~mm}$, and $7.15 \mathrm{~mm}$, respectively. At $100 \%$ concentration, the diameters were $8.30 \mathrm{~mm}, 9.425 \mathrm{~mm}, 9.125 \mathrm{~mm}$, and $13.3 \mathrm{~mm}$, respectively. Negative control using distilled water did not show any growth inhibition zone for E.coli bacteria.

The low inhibition zone produced may occur because the concentration of the pure Extract is too small and due to other factors, such as E.coli bacteria, which are included in the gram-negative bacteria group, which can also affect the study results. It is due to differences in the cell walls of gram-positive bacteria, which have a more straightforward cell wall structure than gram-negative bacteria, which have a reasonably complex bacterial cell wall. The cell wall of grampositive bacteria consists only of peptidoglycan and teichoic acid, while gram-negative bacteria consists of peptidoglycan and an outer membrane that contains three essential components outside of peptidoglycan, namely lipoproteins, lipopolysaccharides and the periplasmic membrane. It causes gram-positive bacteria to be more easily inhibited than gram-negative bacteria. In addition, the influence of physical and chemical factors in the form of seed properties, extract diffusion power, extract stabilization, and microbial concentration on the surface of the medium used can also affect the inhibition zone produced by Sembukan leaf extract against E.coli bacteria.

In another experiment, namely, the test of the bioactive compound of Sembukan leaf extract (Paederia foetida L.) against Staphylococcus aureus by the bioautography method, it can be concluded that the ether extract of Sembukan leaves can provide effectiveness against the growth of Staphylococcus aureus at an Rf value of 0.85 with an inhibition zone of 4.75 . $\mathrm{mm}$, the $\mathrm{Rf}$ value of 0.82 , the inhibition zone was $6.5 \mathrm{~mm}$, the $\mathrm{Rf}$ value was 0.84 the inhibition zone was $6.25 \mathrm{~mm}$. It shows that the leaf extract of Sembukan in specific concentrations can inhibit a microorganism. ${ }^{23}$

The diameter of the inhibition zone in the positive control using the antibiotic ciprofloxacin resulted in the largest inhibition zone from the inhibition zone of other concentration treatments. Ciprofloxacin belongs to the second-generation fluoroquinolone group, which is very active against gram-negative bacteria and is bactericidal by inhibiting DNA gyrase and topoisomerase II, required for bacterial DNA replication, transcription, repair and recombination of gram-negative bacteria, such as E. coli. ${ }^{24}$ Research on The effectiveness of the antibiotic ciprofloxacin against E.coli, which Lisa Kepel carried out in 2015, also showed positive results, and it was found that the diameter of the inhibition zone reached $29 \mathrm{~mm}$ with three repetitions, which means that if the inhibition zone is $>17 \mathrm{~mm}$ it is said that the E.coli bacteria are sensitive against the antibiotic ciprofloxacin. ${ }^{25}$ Aquades as a negative control in this study showed no zone of inhibition. It indicates that the control used does not have antibacterial activity.

The choice of solvent in the extraction process will affect the active compounds that can be dissolved and affect the antibacterial test results. ${ }^{26}$ Ethanol is a polar solvent that is widely used in the extraction process because it is helpful in the synthesis of chemical compounds. Ethanol also has a low boiling point of $79^{\circ} \mathrm{C}$ when compared to other alcohols and is higher than methanol but tends to be safe and harmless when used. The ethanol solvent has two sides consisting of a polar - $\mathrm{OH}$ group and a non-polar $\mathrm{CH}_{2} \mathrm{CH}_{3}$ group, and this non-polar nature allows ethanol to extract the active compounds in Sembukan leaves. ${ }^{26,27}$ Semi-polar ethanol can dissolve polar and non-polar compounds such as tannins, flavonoids, phenols, and essential oils that function as antibacterial. $^{28}$

However, it must also be noted that the extraction process of antibacterial compounds also affects its activity because the solvent of ethanol is semi-polar, so that the extracted compounds are relatively polar. It causes the antibacterial activity of the compound to work less than optimally. Therefore it is necessary to separate the further compound of the crude Extract so that pure antibacterial compounds have more significant inhibitory activity. The polarity of these compounds causes these compounds to penetrate the bacterial cell wall more easily.

\section{CONCLUSION}

Based on the results of the research that has been carried out, it can be concluded that: a) The ethanol extract of the leaves of Sembukan (Paederia foetida L.) has the potential to inhibit the growth of E.coli with statistical test results showing a probability value $(\mathrm{p})=0.000$ or a value $(\mathrm{p})<0.05$; 
and b) There was an increase in the diameter of the bacterial inhibition zone starting from concentrations of $10 \%, 20 \%$, $40 \%, 80 \%$, and $100 \%$. It shows that the higher the concentration of Sembukan leaf extract, the greater the bacterial inhibition zone produced. Thus, it is necessary to do: a) Further research, such as fractionation to determine the activity of specific compounds in Sembukan leaves as antibacterial; b) It is necessary to conduct further research on the comparison of inhibition zones of Sembukan leaf extract against gram-positive and gram-negative bacteria; and c) It is necessary to test for Escherichia coli bacteria with different series, such as the Japanese Collection of Research Bioresources (JCRB), Belgian Coordinated Collection of Micro-organisms (BCCM), the Deutsche Sammlung von Microorganisms und Zellkulturen (DSMZ or German Collection of Microorganisms). and Cell Cultures), and the National Collection of Plant Pathogenic Bacteria (NCPPB).

\section{REFERENCES}

1. Sartika, Ratu Ayu Dewi, Yvonne M. Indrawani, and Trini Sudiarti. "Analisis mikrobiologi Escherichia coli 0157: H7 pada hasil olahan hewan sapi dalam proses produksinya." Makara Kesehatan 2005; 9(1):23-28

2. Mahon, C., D. Lehman, and George Manuselis. "Textbook of Diagnostic Microbiology. 5th Edidtion." Missouri: Elsevier (2014).

3. Zakki, Ghulam Izza. "Pengetahuan Dan Perilaku Preventif Terhadap Bakteri E-Coli Pada Masyarakat Kecamatan Gondomanan di Kota Yogyakarta." PhD diss., Universitas Negeri Semarang, 2015.

4. Jawetz, Ernest, Joseph L. Melnick, and Edward A. Adelberg. "Jawetz, melnick, Adelberg's Medical microbiology." 2001.

5. Welch, Rodney A. "The genus Escherichia." Prokaryotes 2006; 6(1):60-71 https://doi.org/10.1007/0-387-30746-X_3

6. Cavalieri, S. J., R. J. Harbeck, Y. S. McCarter, J. H. Ortez, I. D. Rankin, R. L. Sautter, S. E. Sharp, and C. A. Spiegel. "Manual of antimicrobial susceptibility testing. American Society for Microbiology." Pan American Health Organization: Washington, DC, USA 2005

7. KemenKes, R. I. "Riset kesehatan dasar (Riskesdas) 2013." Jakarta: Badan Penelitian dan Pengembangan Kesehatan Kementrian Kesehatan Republik Indonesia 2013.

8. KeMenKes, R. I. "Profil kesehatan Indonesia tahun 2015." Jakarta Kementeri Kesehat Republik Indones 2016.

9. Maharani, Krisnina. "Uji Antibakteri Ekstrak Kulit Buah dan Biji Manggis (Garcinia mangostana) pada Bakteri Penyebab Jerawat (Staphylococcus epidermidis) dengan Menggunakan Solven Etanol." PhD diss., UNIVERSITAS AIRLANGGA, 2012.

10. Nurcahyanti, A. D. R., and J. Wandra. "Sembukan kurang sedap namun berkhasiat hebat." Bios: Salatiga 2012.

11. Handrianto, Prasetyo. "Analisis Kandungan Kimia Daun Dan Batang Sembukan (Paederia Foetida) Dengan Menggunakan 2 Pelarut Yang Berbeda." Journal of Pharmacy and Science 2018; 3(2):23-27. https://doi.org/10.53342/pharmasci.v3i2.112

12. Leininger, Dagny Jayne, Jerry Russel Roberson, and Francois Elvinger. "Use of eosin methylene blue agar to differentiate Escherichia coli from other gram-negative mastitis pathogens." Journal of veterinary diagnostic investigation 2001; 13(3):273275. https://doi.org/10.1177/104063870101300319
13. Kumari, Preeti, Chandrawati Kumari, and Poornima Shekhar Singh. "Phytochemical screening of selected medicinal plants for secondary metabolites." Int. J. Life. Sci. Scienti. Res 2017; 3(4):1151-1157. https://doi.org/10.21276/ijlssr.2017.3.4.9

14. Saifudin, Azis. Senyawa alam metabolit sekunder teori, konsep, dan teknik pemurnian. Deepublish, 2014.

15. Abriyanto, Adityas Elvian, Sabikis Sabikis, and Sudarso Sudarso. "Aktivitas anti-fungi ekstrak etanol daun sembukan (Paederia foetida L) terhadap Candida albicans." PHARMACY: Jurnal Farmasi Indonesia (Pharmaceutical Journal of Indonesia) 2012; 9(3).

16. Utami, Evy T., Rebecca A. Kuncoro, Islami Rahma Hutami, F. T. Sari, and J. Handajani. "Efek antiinflamasi ekstrak daun sembukan (Paederia scandens) pada tikus wistar." Majalah Obat Tradisional 2011; 16(2):95-100.

17. Ryan, K. J., and C. G. Ray. "Mycoplasma. Ryan KJ, Ray CG. Sherris Medical Microbiology." (2014).

18. Sikumalay, Adriyan, Netti Suharti, and Machdawaty Masri. "Efek Antibakteri dari Rebusan Daun Sambiloto (Andrographis paniculata Nees) dan Produk Herbal Sambiloto Terhadap Staphylococcus Aureus." Jurnal Kesehatan Andalas 2016; 5(1). https://doi.org/10.25077/jka.v5i1.468

19. Senja, Rima Yulia, E. Issusilaningtyas, A. K. Nugroho, and E. P. Setyowati. "Perbandingan metode ekstraksi dan variasi pelarut terhadap rendemen dan aktivitas antioksidan ekstrak kubis ungu (brassica oleracea l. var. capitata f. rubra)." Traditional Medicine Journal 2014; 19(1):43-48

20. Sa'adah, Lailis. "Isolasi dan identifikasi senyawa tanin dari daun belimbing wuluh (averrhoa bilimbi l.)." Skripsi tidak diterbitkan. Malang: Fakultas Sains dan Teknologi-Universitas Islam Negeri (UIN) Maulana Malik Ibrahim 2010.

21. Tetti, Mukhriani. "Ekstraksi, pemisahan senyawa, dan identifikasi senyawa aktif." Jurnal Kesehatan 2014; 7(2).

22. Stout, John David. "Aspects of the microbiology and oxidation of Wicken Fen soil." Soil Biology and Biochemistry 1971; 3(1):925. https://doi.org/10.1016/0038-0717(71)90027-7

23. Usman, Samsidar, and Ismail Ibrahim. "Uji Aktivitas Senyawa Bioaktif Antimikroba Dari Ekstrak Daun Sembukan (Paederia Foetida L.) Pada Bakteri Staphylococcus Aureus Dengan Metode Bioautografi." Media Farmasi 2019; 13(2):42-48. https://doi.org/10.32382/mf.v13i2.881

24. Rachmad, Basuki, Wiria Saputri, A. S. Yandi, Andi Setiawan, and Mulyono Mulyono. "Isolasi dan Identifikasi Gen Resisten Ciprofloxacin pada Isolat Escherichia coli MDR Ciprofloxacin dari Penderita ISK di RSUDAM Provinsi Lampung." Jurnal Kedokteran Universitas Lampung 2017; 1(3):487-497.

25. Kepel, Lisa, and Fona Budiarso. "Uji Resistensi Bakteri Escherichia Coli Yang Diisolasi Dari Plak Gigi Terhadap Merkuri Danantibiotik Siprofloksasin." eBiomedik 3, no. 1 (2015). https://doi.org/10.35790/ebm.3.1.2015.6604

26. Azis, Tamzil, Sendry Febrizky, and Aris D. Mario. "Pengaruh jenis pelarut terhadap persen yieldalkaloiddari daun salam india (Murraya koenigii)." Jurnal Teknik Kimia 2014; 20(2).

27. Jain J, Tikare S, Mahuli A. "Antifungal activity of ginger extract on Candida albicans: An in-vitro study." Journal of Dental Sciences and Research 2011; 2(2):18-21.

28. Fadillah, Haris. "Optimasi Sabun Cair Antibakteri Ekstrak Etano Rimpang Jahe Merah (Zingiber Officinale Rosc. Var. Rubrum) Variasi Virgin Coconut Oil (Vco) Dan Kalium Hidroksida (Koh) Menggunakan Simplex Lattice Design." Jurnal Mahasiswa Farmasi Fakultas Kedokteran UNTAN 2014; 1(1). 